\title{
Green turtle herbivory dominates the fate of seagrass primary production in the Lakshadweep islands (Indian Ocean)
}

\author{
Nachiket Kelkar ${ }^{1, *}$, Rohan Arthur $^{1}$, Nuria Marba $^{2}$, Teresa Alcoverro ${ }^{1,3}$ \\ ${ }^{1}$ Oceans and Coasts Program, Nature Conservation Foundation, IV Cross 3076/5, Gokulam Park, Mysore 570002, India \\ ${ }^{2}$ Institut Mediterrani d'Estudis AvanÇats (CSIC-UIB), Miquel Marquès 21, 07190 Esporles, Illes Balears, Spain \\ ${ }^{3}$ Centre d'Estudis Avançats de Blanes (CEAB-CSIC), Accés cala St. Francesc 14, 17300 Blanes, Girona, Spain
}

\begin{abstract}
Historical global declines of megaherbivores from marine ecosystems have hitherto contributed to an understanding of seagrass meadow production dominated by detrital pathways - a paradigm increasingly being questioned by recent re-evaluations of the importance of herbivory. Recoveries in green turtle populations at some locations provide an ideal opportunity to examine effects of high megaherbivore densities on the fate of seagrass production. We conducted direct field measurements of aboveground herbivory and shoot elongation rates in 9 seagrass meadows across 3 atolls in the Lakshadweep Archipelago (India) representing a gradient of green turtle densities. Across all meadows, green turtles consumed an average of $60 \%$ of the total leaf growth. As expected, herbivory rates were positively related to turtle density and ranged from being almost absent in meadows with few turtles, to potentially overgrazed meadows (ca. $170 \%$ of leaf growth) where turtles were abundant. Turtle herbivory also substantially reduced shoot elongation rates. Simulated grazing through clipping experiments confirmed this trend: growth rates rapidly declined to almost half in clipped plots relative to control plots. At green turtle densities similar to historical estimates, herbivory not only dominated the fate of seagrass primary production but also drastically reduced production rates in grazed meadows. Intensive turtle grazing and associated movement could also modify rates of detrital cycling, leaf export and local carbon burial, with important consequences for the entire seascape.
\end{abstract}

KEY WORDS: Fate of seagrass production · Herbivory pathway · Megaherbivores · Green turtles · Thalassia hemprichii $\cdot$ Cymodocea rotundata $\cdot$ Lakshadweep islands

Resale or republication not permitted without written consent of the publisher

\section{INTRODUCTION}

The drastic decline of marine megaherbivores from the world's oceans over the last few centuries (Jackson 1997, 2001) has contributed to a general uncertainty of their functional contribution to the trophic dynamics of seagrass meadows. The resurgence of interest in re-evaluating the role of herbivory in seagrass dynamics (Thayer et al. 1984, Cyr \& Pace 1993, Valentine \& Heck 1999, 2001, Alcoverro \& Mariani 2004, Valentine \& Duffy 2006) raises the question of how these systems functioned under historically high levels of herbivory (Bjorndal \& Jackson 2003, Heck \& Valentine 2006).

Green turtle Chelonia mydas populations have recently begun to show surprising recoveries in some locations across their range (e.g. Hawaii, Mayotte, Borneo, Lakshadweep; e.g. Balazs 2004, Seminoff 2004, Broderick et al. 2006, Chaloupka et al. 2008, Ballorain et al. 2010, Fourqurean et al. 2010, Lal et al. 2010, Christianen et al. 2012) as a result of active conservation efforts and the decline of large predators such as sharks (Heithaus et al. 2008). Extant high-density populations provide an excellent oppor- 
tunity to reconstruct the ecology of seagrass meadows when megaherbivores were abundant (Valentine \& Heck 1999). In fact, recent studies on these populations are already throwing light on ecosystemlevel effects of green turtle herbivory that include modification in seagrass biomass, structure and overgrazing of meadows (Lal et al. 2010, Fourqurean et al. 2010, Christianen et al. 2012). However, in the absence of direct field measures of herbivory, the magnitude of the herbivory pathway in modifying seagrass production fate remains unclear (see Prado et al. 2007).

In seagrass ecosystems not dominated by herbivores, physical agents (primarily marine currents) mainly regulate the fate of primary production by determining the proportion of in situ and ex situ decomposition pathways (Duarte \& Cebrián 1996, Cebrián et al. 1997, 2000, Mateo et al. 2006). However, when herbivores are abundant, they can have important consequences for nutrient cycling and leaf export (Valentine \& Heck 1999, Valentine et al. 2004). Herbivores with low mobility tend to increase in situ decomposition and carbon burial, as pre-digested plants are less prone to be exported (Duffy \& Hay 1994, Cebrián et al.1997, 1998, Heck et al. 2008). In contrast, when widely ranging large herbivores (such as green turtles) are common, the bulk of leaf export is driven by their movement (Hay et al. 1988). Thus, when the herbivory pathway dominates, it can have profound consequences for the entire seascape (Lundberg \& Moberg 2003, Burkholder et al. 2011).

In this context, it is critical to evaluate the magnitude and importance of herbivory towards the fate of seagrass primary production. Direct field measures of herbivory are only recently becoming available and indicate that earlier indirect measurements may have considerably underestimated the herbivory pathway (Prado et al. 2007). For instance, direct measurements of fish herbivory have shown that it can represent 50 to $100 \%$ of primary production in some regions (Kirsch et al. 2002, Prado et al. 2007, Unsworth et al. 2007) compared with previous indirect estimates that concluded that only about $10 \%$ of primary production was transferred to herbivores (Cebrián \& Duarte 1998, Williams \& Heck 2001). Direct field measures have also helped identify clear mechanisms, such as herbivore density, resource availability and feeding preferences, that influence herbivory rates in seagrass meadows (Vergés et al. 2007, Prado et al. 2008), and how these drivers interact will eventually determine the intensity and persistence of seagrass herbivory (Williams 1988, Fourqurean et al. 2010). Seagrass species may have different inherent evolutionary adaptations to withstand herbivory pressure (Cronin \& Hay 1996, Domning 2001, Nakanishi et al. 2009) which could result in habitat-wide compositional shifts under sustained herbivory - extreme rates of removal could even threaten meadow survival (Eklof et al. 2008, Fourqurean et al. 2010). At lower rates of offtake, it is possible that seagrass meadows and their dominant herbivores exist in a dynamic equilibrium between offtake and production, determined by herbivore feeding rates, movement patterns, plant growth and composition, among others.

Green turtle populations in the Lakshadweep Archipelago (Indian Ocean) have recently undergone major increases in shallow seagrass lagoons. At one lagoon (Agatti), high green turtle densities have persisted for over a decade (Lal et al. 2010), and these numbers are gradually increasing in other lagoons. It is difficult to speculate on what has triggered these changes but the increase has coincided with a local ban on the hunting of turtles for oil, overfishing of top predators such as tiger sharks (Heithaus et al. 2008) and immigration of turtles from nearby regions in the western Indian ocean in response to effective turtle conservation programs (Broderick et al. 2006). These high population densities provide an ideal context to evaluate the importance of herbivory as a transfer pathway for primary production in seagrass meadows with large feeding aggregations of megaherbivores. To estimate the extent of the herbivory pathway in these atolls we used direct measurements of aboveground herbivory and production rates from 9 meadows with a range of turtle densities in the Lakshadweep archipelago. We hypothesized that herbivory at these meadows would directly reduce seagrass production. To test this hypothesis, we compared primary production in meadows with different levels of herbivory pressure and validated these observations with seagrass clipping experiments that simulated turtle cropping rates observed in these meadows.

\section{MATERIALS AND METHODS}

\section{Study area}

The Lakshadweep Archipelago (Arabian Sea, Indian Ocean) comprises 12 atolls and submerged banks, with 36 islands covering a total area of $32 \mathrm{~km}^{2}$. The islands are low-lying $(<5 \mathrm{~m}$ above sea level) and occur between $8^{\circ}$ to $12^{\circ} \mathrm{N}$ and $71^{\circ}$ to $74^{\circ} \mathrm{E}$ at the northern end of the Laccadive-Chagos submarine 
ridge. Seagrass meadows occur in shallow lagoons of the Lakshadweep islands. The study was conducted over 2 yr (2010 to 2011) in the well-formed seagrass meadows of 3 different lagoons: Agatti $\left(16.8 \mathrm{~km}^{2}\right)$, Kadmat $\left(20.9 \mathrm{~km}^{2}\right)$ and Kavaratti $\left(6.2 \mathrm{~km}^{2}\right)$. Three seagrass meadows were selected in the Agatti lagoon, 4 in Kadmat, and 2 in Kavaratti lagoon, representing ca. $70 \%$ of the seagrass meadows of this archipelago (Jagtap 1991). These seagrass meadows have been present in the 3 lagoons in similar proportions for at least the last $15 \mathrm{yr}$ (R. Arthur pers. obs., local fishers pers. comm.). A total of 8 seagrass species have been reported from these meadows with 2 species (Thalassia hemprichii and Cymodocea rotundata) clearly dominant (Jagtap 1991).

\section{Turtle densities}

Four turtle surveys were conducted at each island in 2010 and 2011. In each lagoon, 3 observers counted turtles in a $10 \times 300 \mathrm{~m}$ belt between grid points ( $\mathrm{n}=70$ to 232 , based on lagoon area), on both sides of the boat, for each point on a $300 \times 300 \mathrm{~m}$ grid. The number of turtles counted along each transect was assigned to the subsequent grid point. We surveyed turtles only when sighting conditions were excellent. Water clarity was very high (horizontal visibility of ca. $20 \mathrm{~m}$ ) at all lagoons, with uniform low wave-flow velocity. The lagoons are very shallow (mean depth $=$ $2.2 \mathrm{~m}$, max. depth $<5 \mathrm{~m}$ ), making it easy to reliably scan the substrate for turtles (Lal et al. 2010). Changes in turtle numbers with tidal variation were negligible, with most turtles staying inside the respective lagoons throughout the sampling season. Presence or absence of seagrass was recorded at each grid point to estimate the areal extent of seagrass meadows. Meadow-specific turtle density was calculated by averaging the number of turtles across all grid points in the areas within a seagrass meadow.

\section{Production and herbivory}

We were interested in obtaining absolute rather than relative rates of herbivory at each meadow so that they were directly comparable to leaf growth rates. Hence, we used direct field measures to estimate in situ rates of herbivory (see Prado et al. 2007). We sampled 50 random shoots of Thalassia hemprichii and Cymodocea rotundata in proportion to their abundance at each meadow. Leaf elongation rate (shoot leaf growth, cm shoot ${ }^{-1} \mathrm{~d}^{-1}$ ) was obtained by marking these shoots in situ with a hypodermic needle (Short \& Coles 2001, Prado et al. 2007). Briefly, the length of each leaf per shoot was measured, the number of leaves counted, and the sheath base marked with a needle. Only shoots that did not have pre-existing grazing marks were selected. After an interval of 3 to $5 \mathrm{~d}$, total leaf length was again measured and leaf elongation was calculated as the distance between the leaf scar mark and the sheath base. Total shoot elongation was obtained as the sum of leaf elongation for all leaves within a shoot divided by the elapsed time. We calculated herbivory rate (shoot herbivory in $\mathrm{cm}$ shoot ${ }^{-1} \mathrm{~d}^{-1}$ ) by adding shoot elongation to the initial length, and subtracting the total from the final length (see Prado et al. 2007). Any lost leaves were not considered in our calculations, and only leaves that had clear herbivory marks were assigned to each type of herbivore (fish or green turtle; Fig. 1). This resulted in slightly conservative measures of herbivory, as it included senescent leaves as well as leaves that could have been fully lost to herbivores, however this method minimized the possibility of overestimating herbivory. Herbivory rates were assigned to the different herbivores depending on the bite type present on the top of the leaf (fish, sea urchins or green turtles (Fig. 1). We did not find any sea urchin bite marks, thus matching our field observations that indicated that sea urchins were virtually absent from these meadows. Other

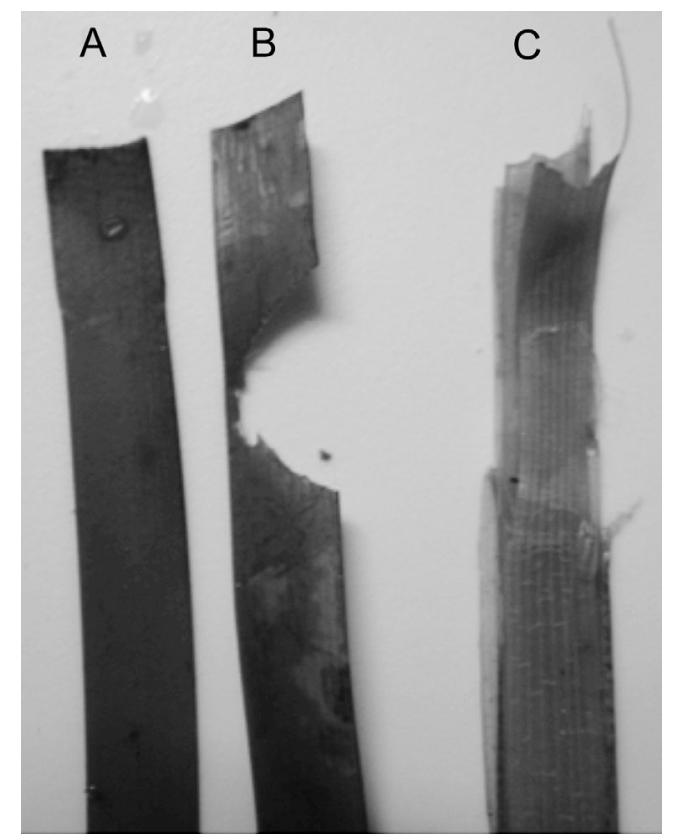

Fig. 1. Identification of turtle herbivory marks on natural seagrass shoots of Thalassia hemprichii. (A) Clipped with scissors, (B) fish bite, (C) cropped by green turtle 
potential herbivores such as waterfowl were not present at our sampling locations (R. Arthur pers. obs.). Sampling at all meadows was conducted during the pre-monsoon season (between February and March) to avoid seasonal variations.

\section{Clipping experiment}

We set up experimental 'clipping plots' of $1 \mathrm{~m}^{2}$ to simulate turtle grazing (e.g. Moran \& Bjorndal 2005) in seagrass patches in Kadmat where turtles were nearly absent during the experimental period. The meadow was co-dominated by Thalassia hemprichii and Cymodocea rotundata. We manually clipped shoots with a scissors at rates similar to shoot cropping rates recorded in the Agatti lagoon (where turtles were very abundant). A total of 5 clipped and 5 control plots were set up in 2011. Shoot densities between clipped and control plots did not differ significantly at the start of the experiment (ANOVA: $F=$ $0.712, \mathrm{p}=0.423)$. Clipping was continued over a period of $130 \mathrm{~d}$ with clipping treatments approximately every fortnight (i.e. 10 times). At meadows where grazing is intense, we observed turtles cropping seagrass very close to the base of the shoot, removing a few centimeters of the shoot (ca. 5 to $10 \mathrm{~cm}$ ) with each bite with an average loss of around $1 \mathrm{~cm}$ shoot $\mathrm{d}^{-1}$ (see results). Turtles were observed to typically graze for a few days at one location before moving between patches within the meadow. Our clipping experiment was designed to mimic natural rates of green turtle herbivory as closely as possible. Each clipping resulted in a herbivory rate of ca. $10 \mathrm{~cm} \mathrm{shoot}^{-1}$ fortnight $^{-1}$, which was similar to our observed rates of high green turtle herbivory (see 'Results: Clipping experiment'). We used fortnightly clipping over more frequent clipping, since the former closely mimicked the natural mode of turtle grazing. Towards the end of the experiment seagrass shoot elongation was measured as described above, and compared across clipped and control plots for both species. During the experiment we did not observe any turtle herbivory marks in the control or treatment plots confirming the absence of turtles in the area.

\section{Statistical analyses}

We explored relationships between turtle densities, shoot herbivory rates and shoot elongation with simple and mixed effects regression models.
We first explored the mixed models with species as a fixed effect and island as a random effect. The possibility of over-fitting of the mixed models could not be ruled out given the number of parameters relative to the sample size. Additionally, species did not have a significant effect in the mixed models $(z=-0.96, p=0.34)$ and the random effect of individual atolls was low $(0.34 \pm 0.59$, mean \pm SD). Although mixed effects models had slightly lower Akaike Information Criterion corrected (AICc) scores than simple linear models, we chose to use linear models to avoid over-fitting. The best overall model had turtle herbivory rate as the predictor of shoot elongation rates. To further discount the possibility that the different proportions of Thalassia hemprichii and Cymodocea rotundata across meadows influenced our observations, we tested for differences in shoot elongation rates of both species in the control plots. No significant differences were observed in elongation rates $(\mathrm{cm}$ shoot growth $\mathrm{d}^{-1}$ ) between species ( $t$-test, $\mathrm{df}=$ 11.5, $\mathrm{p}=0.87$; Fig. 4) allowing us to safely average over all randomly collected shoots per meadow (total of 50 shoots) for all further analysis. In the clipping experiment, we used a 2-way ANOVA to assess differences in shoot elongation rate between clipped and control treatments as fixed factors (all measured shoots averaged for each plot) and species as a fixed factor. All statistical analyses were conducted in the software R 2.13.1 (R Development Core Team 2011).

\section{RESULTS}

\section{Turtle densities, leaf growth and herbivory rates}

Turtle densities ranged from 0 to 30 ind. per $\mathrm{km}^{2}$ across meadows (Table 1, Fig. 2). Shoot elongation rates in the different meadows ranged from 238 to $3937 \mathrm{~cm}$ shoots $\mathrm{m}^{-2} \mathrm{~d}^{-1}$ (average $=1100 \mathrm{~cm}$ shoots $\mathrm{m}^{-2} \mathrm{~d}^{-1}$; Table 1, Fig. 2). Turtle herbivory rates (Table 1, Fig. 2) accounted for an average of $59 \pm$ $52 \%$ of shoot growth per day. The proportion of turtle herbivory differed widely between meadows (Table 1), ranging from $0 \%$ to as much as $170 \%$ of shoot elongation. In our visual estimates of the leaf tips, more than $99 \%$ of herbivory marks were clearly assigned to green turtles. This was validated by a clear correlation between turtle herbivory rates $\left(\mathrm{cm}\right.$ shoot $\left.^{-1} \mathrm{~d}^{-1}\right)$ and turtle densities (linear regression: herbivory rate $=197.4 \times \log$ (turtle density) + 37.38; $\mathrm{R}^{2}=0.56, \mathrm{p}=0.02 ;$, Fig. 3). Within each 
Table 1. Meadow-specific turtle densities, shoot density for each seagrass species $(\mathrm{TH}=$ Thalassia hemprichii, $\mathrm{CR}=$ Cymodocea rotundata), elongation and herbivory rates and proportion of production consumed (herbivory/shoot growth) by green turtles at 9 meadows in the Lakshadweep islands. Values are means \pm SD

\begin{tabular}{|c|c|c|c|c|c|c|}
\hline Atoll & $\begin{array}{c}\text { Meadow } \\
\text { (number of turtle } \\
\text { point counts) }\end{array}$ & $\begin{array}{l}\text { Turtle density } \\
\text { (turtles } \mathrm{km}^{-2} \text { ) }\end{array}$ & $\begin{array}{l}\text { Shoot density } \\
\left({\text { shoots } \mathrm{m}^{-2} \text { ) }}\right. \\
\mathrm{N}=10 \text { plots } \\
\text { per meadow }\end{array}$ & $\begin{array}{c}\text { Elongation } \\
\text { (leaf growth) rate } \\
\left(\mathrm{cm} \mathrm{m}^{-2} \mathrm{~d}^{-1}\right) \\
\mathrm{N}=50 \text { shoots } \\
\text { per meadow }\end{array}$ & $\begin{array}{l}\text { Herbivory rate } \\
\left(\mathrm{cm} \mathrm{m}^{-2} \mathrm{~d}^{-1}\right) \\
\mathrm{N}=50 \text { shoots } \\
\text { per meadow }\end{array}$ & $\begin{array}{l}\text { Proportion of } \\
\text { total leaf growth } \\
\text { consumed by } \\
\text { herbivores } \\
(\%, \text { rounded })\end{array}$ \\
\hline Agatti & North (58) & $17.93 \pm 0.82$ & $\begin{array}{c}\text { TH } 32 \pm 29.92 \\
\text { CR } 275.2 \pm 87.2\end{array}$ & $273.408 \pm 45.20$ & $196.7 \pm 152.49$ & 72 \\
\hline Agatti & Central (57) & $1.64 \pm 2.05$ & $\begin{array}{c}\text { TH } 0 \\
\text { CR } 195.2 \pm 90.7\end{array}$ & $161.528 \pm 34.38$ & $57.81 \pm 80.38$ & 36 \\
\hline Agatti & South (58) & $4.53 \pm 4.51$ & $\begin{array}{c}\text { TH } 16 \pm 35.4 \\
\text { CR } 803.2 \pm 354.08\end{array}$ & $655.21 \pm 130.52$ & $450.94 \pm 203.57$ & 69 \\
\hline Kadmat & North (78) & $2.95 \pm 0.1$ & $\begin{array}{c}\text { TH } 1168 \pm 202.4 \\
\text { CR } 0\end{array}$ & $1006.48 \pm 48.29$ & $342.04 \pm 101.2$ & 34 \\
\hline Kadmat & Central (77) & $5.97 \pm 0.92$ & $\begin{array}{c}\text { TH } 784 \pm 282.72 \\
\text { CR } 3.2 \pm 7.15\end{array}$ & $705.6 \pm 47.60$ & $317.28 \pm 175.343$ & 45 \\
\hline Kadmat & South (77) & $0.72 \pm 0.01$ & $\begin{array}{l}\text { TH } 393.6 \pm 152.3 \\
\text { CR } 1382 \pm 469.9\end{array}$ & $3937.39 \pm 212.49$ & 0 & 0 \\
\hline Kadmat & South (77) & $0.9 \pm 0.55$ & $\begin{array}{c}\text { TH } 176 \pm 74.7 \\
\text { CR } 1384 \pm 311.68\end{array}$ & $2262 \pm 135.24$ & 0 & 0 \\
\hline Kavaratti & North (34) & $6.53 \pm 1.03$ & $\begin{array}{c}\text { TH } 152 \pm 44 \\
\text { CR } 576 \pm 83.2\end{array}$ & $495.04 \pm 43.74$ & $500.667 \pm 132.22$ & 101 \\
\hline Kavaratti & South (36) & $29.98 \pm 15.05$ & $\begin{array}{l}\text { TH } 112 \pm 74.7 \\
\text { CR } 656 \pm 360\end{array}$ & $311.118 \pm 105.43$ & $535.296 \pm 682.31$ & 172 \\
\hline
\end{tabular}

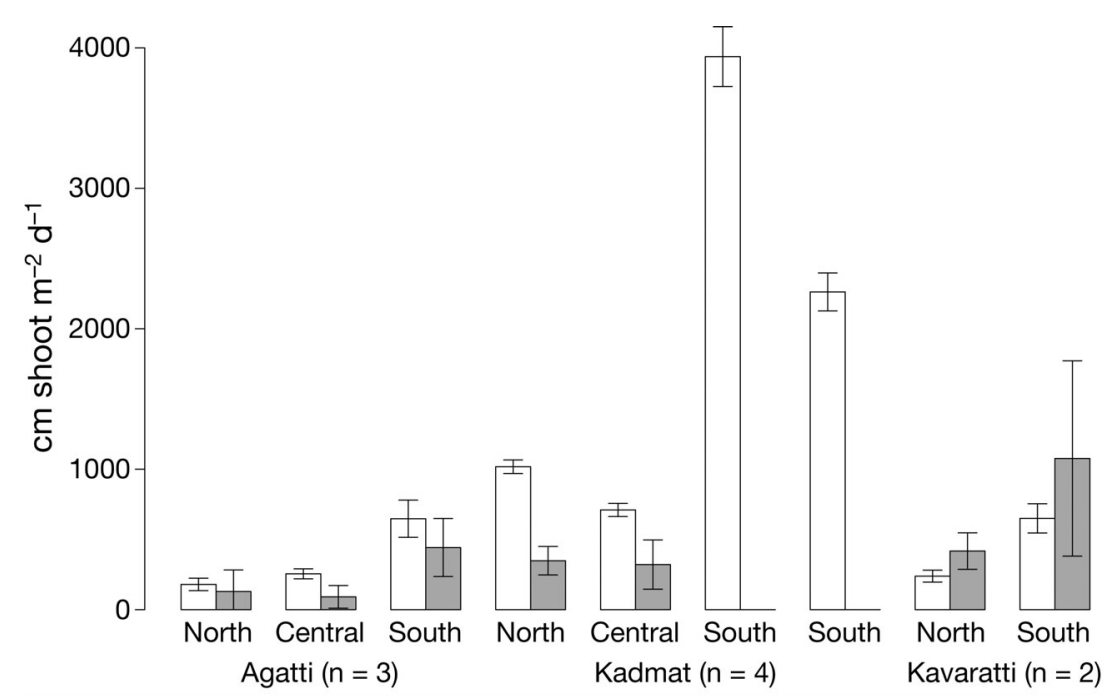

Fig. 2. Shoot elongation (white bars) and herbivory (gray bars) rates (mean $\pm \mathrm{SD}$ ) in 9 meadows sampled across 3 islands: Agatti, Kadmat and Kavaratti. $\mathrm{n}=50$ sampled shoots per meadow

meadow, herbivory was patchy in space as a result of the spatial variation in the foraging behavior of turtles. As expected, seagrass shoot elongation rates were relatively uniform across the meadow (variance: mean ratios lower for shoot elongation than for herbivory rates; Table 1).

\section{Effects of turtle herbivory on shoot elongation}

Shoot elongation (cm growth shoot ${ }^{-1}$ $\mathrm{d}^{-1}$ ) declined sharply with increasing herbivory rates, beyond a threshold of $400 \mathrm{~cm}$ shoot eaten $\mathrm{m}^{-2} \mathrm{~d}^{-1}$ (nonlinear least-squares regression: shoot elongation rate $=2888.56-401.22 \times$ $\log$ (herbivory rate); where slope = $-401.22[\mathrm{p}=0.004]$, intercept $=$ 2888.56 [p $<0.001$ ]; Fig. 4).

\section{Clipping experiment}

Shoot elongation for both Thalassia hemprichii and Cymodocea rotundata was lower by almost half in clipped plots relative to control plots (Fig. 5, ANOVA: $F_{1,12}=11.84, \mathrm{p}=0.008$, and $F_{1,14}=30.64, \mathrm{p}<0.001$ for $T$. hemprichii and $C$. rotundata, respectively). Total shoot elongation was significantly affected by clipping but not by species clipped (ANOVA: clipping treatment effect, $F_{1,26}=$ $34.92, \mathrm{p}<0.001$; seagrass species effect, $F_{1,26}=0$, $\mathrm{p}=0.99)$. 


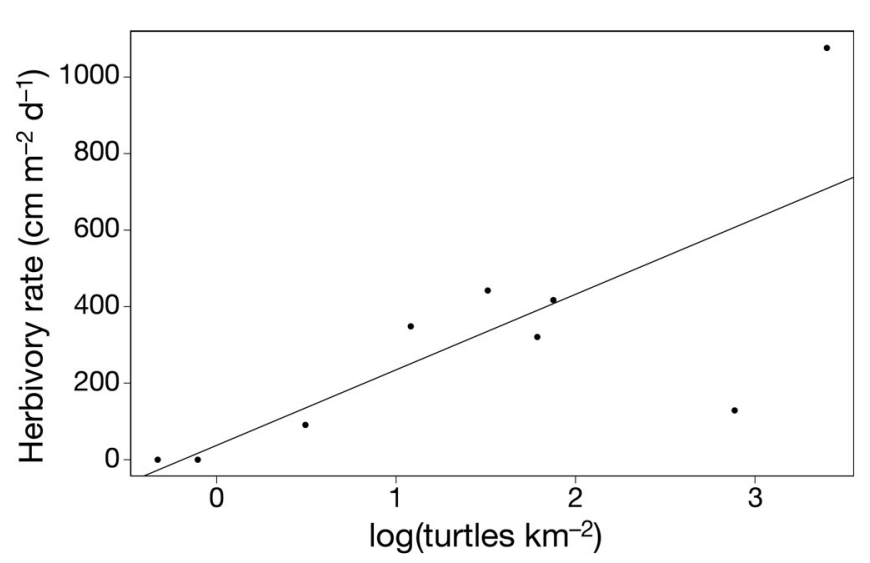

Fig. 3. Linear regression between herbivory rate $(\mathrm{cm}$ shoot eaten $\mathrm{m}^{-2} \mathrm{~d}^{-1}$ ) and turtle densities (turtles $\mathrm{km}^{-2}$ ) from 9 meadows across the Lakshadweep islands (herbivory rate $=$ $37.38+197.4 \times \log \left(\right.$ turtle density) $\left.{ }_{i} \mathrm{R}^{2}=0.56, \mathrm{p}=0.02\right)$

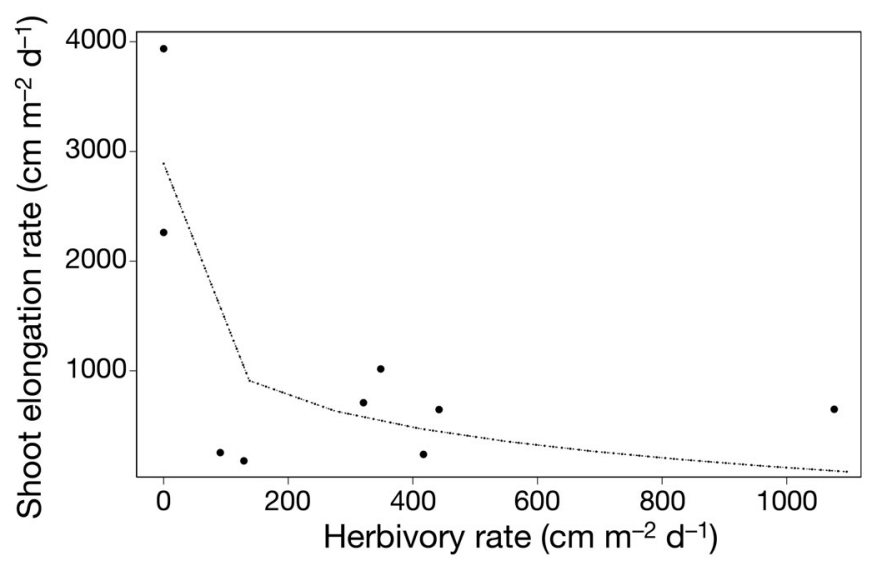

Fig. 4. Non-linear regression $(y=B+A \times \log [x])$ between shoot elongation rate ( $\mathrm{cm}$ shoot growth $\mathrm{m}^{-2} \mathrm{~d}^{-1}$ ) and herbivory rate $\left(\mathrm{cm}\right.$ shoot eaten $\mathrm{m}^{-2} \mathrm{~d}^{-1}$ ) from 9 meadows across the Lakshadweep islands (shoot elongation rate $=2888.56-$ $401.22 \times \log$ (herbivory rate), where slope $=-401.22$, $\mathrm{p}=0.004$, intercept $=2888.56, \mathrm{p}<0.001$ )

\section{DISCUSSION}

Our results indicate that in the Lakshadweep archipelago, green turtles can consume an average of almost $60 \%$ of total seagrass production and thus play a vital role in modifying the fate of tropical seagrass production pathways. This role varied greatly between meadows: at some locations herbivory accounted for nearly double the seagrass production, suggesting overgrazing, while at other meadows herbivory was almost absent. As expected, green turtle density was correlated with direct estimates of turtle herbivory rates across the sampled meadows. However, the deviation from a perfect correlation suggests that herbivory rates depend not merely on

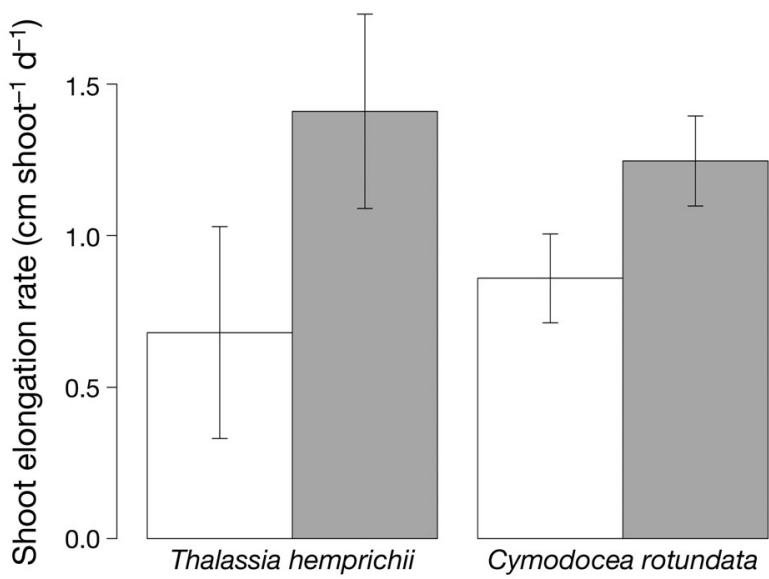

Fig. 5. Effects of clipping (mean $\pm \mathrm{SD}$ ) on species-specific leaf elongation rates of Thalassia hemprichii and Cymodocea rotundata. Clipped plots $(n=5)$ are shown by white bars, and control plots $(n=5)$ by gray bars. Differences between control and treatment plots are significant $(p<0.001)$ for both species

herbivore density, but may also be influenced by available seagrass resources or foraging preferences (Vergés et al. 2007, Prado et al. 2008). This emphasizes the importance of using direct field measures of herbivory. Interestingly, beyond a threshold of green turtle herbivory, seagrass meadows appeared to quickly respond by reducing shoot elongation; a trend confirmed by our clipping experiments (Fig. 3). Taken together, these results suggest that highdensity green turtle populations do not only dominate the fate of the production pathway but also reduce rates of meadow production itself.

The multiple anti-herbivory mechanisms that seagrasses possess strongly suggest that herbivory may have been globally much more important in the past when megaherbivore abundances were significantly higher (Preen 1995, Valentine \& Heck 1999, Domning 2001, Moran \& Bjorndal 2005, Heck \& Valentine 2006, Nakanishi et al. 2009). At the generally low densities at which green turtles are currently found in most regional seas, the relatively low levels of herbivory appear to increase leaf growth rates (e.g. Valentine et al. 1997, Moran \& Bjorndal 2005, 2007, Aragones et al. 2006). However, recent observations of high-density populations of green turtles in some locations around the world are offering unique insights into the functioning of meadows at potential historical densities. These studies indicate that turtle overgrazing can cause profound consequences to seagrass meadows including structural changes, meadow collapse, and even extinction (Fourqurean et al. 2010, Ballorain et al. 2010, Christianen et al. 2012). Earlier studies in the Lakshadweep islands 
established that at high densities turtles act as significant ecosystem modifiers, affecting the structure and morphology of seagrass meadows through herbivory (Lal et al. 2010). The present study extends this work and helps establish large-scale, direct field measures of green turtle grazing in relation to seagrass shoot elongation as critical to understanding ability of seagrass meadows to cope with grazing pressure.

At high rates of herbivory across regional scales, as described in this study, green turtles can substantially modify the fate of seagrass primary production. This shift from primarily detrital-dominated to herbivory-dominated pathways in seagrass meadows may significantly affect energy transfer across entire seascapes and be highly dependent both on the residence time and movement behaviour of green turtles (Bjorndal 1997, Aragones et al. 2006). On the one hand, being mobile species with very large home ranges, detrital pathways modified by green turtles could impact nutrient cycling and carbon fluxes by increasing long-distance leaf export (Hay et al. 1988, Cebrián 1999, Mateo et al. 2006). For instance, in the Lakshadweep islands, green turtles may potentially contribute to and subsidize nutrient flows to coral reefs (turtle resting areas) from adjacent seagrass meadows (feeding areas), a pattern that has been observed elsewhere (e.g. Thayer \& Engel 1982, Ballorain et al. 2010, Christianen et al. 2012). On the other hand, high residence times of turtles within lagoons can accelerate local leaf decomposition rates, altering carbon burial patterns, which in turn can impact blue carbon sequestration potential that is increasingly being recognized as an important ecosystem service of seagrass meadows (Thayer \& Engel 1982, Bjorndal 1985, 1997, Fourqurean et al. 2012).

The present study shows that intensive grazing by green turtles can alter the fate, as well as the rate, of aboveground leaf growth. Seagrass meadows in the Lakshadweep islands may have a rather limited ability to cope with the observed rates of green turtle herbivory. There appear to be clear thresholds of herbivory that these meadows can sustain without reducing production (ca. $300 \mathrm{~cm}$ shoot eaten $\mathrm{m}^{-2} \mathrm{~d}^{-1}$, see Fig. 3). Clipping experiments confirm these results, with a clear and substantial decline in shoot elongation rates of both seagrass species after 4 mo of repeated simulated grazing.

Our direct and experimental measures add further confirmation to earlier, largely experimental studies showing that turtle herbivory can significantly lower seagrass production (Zieman et al. 1984, Williams 1988, Aragones 1996, Cebrián et al. 1998, Kuiper-
Linley et al. 2007, Ballorain 2010, Ballorain et al. 2010). The measured declines in production in the Lakshadweep lagoons are considerably higher than these previous reports, which overlap with only the lower range of estimates from the Lakshadweep meadows. These major declines in seagrass production could have serious negative consequences for macroinvertebrate and fish communities that use these meadows (Unsworth \& Cullen 2010, Vonk et al. 2010). The reduction in seagrass production along with the fact that green turtles can contribute to or modify patterns of export may have important impacts on adjacent ecosystems that depend on seagrass meadows for the range of ecological functions they perform (Bjorndal \& Jackson 2003, Heck et al. 2008). This study provides a basis for assessing these multiple linkages (Burkholder et al. 2011), and further strengthens the growing shift in our understanding of herbivory as a crucial influence on seagrass meadow function and ecosystem services, especially in tropical seas.

At another level, our study raises interesting questions of how 'pristine' seagrass meadows, with their full complement of megaherbivores, could have tolerated the high magnitudes of herbivory they would have historically been subject to. It is difficult to argue that present regionally high densities of green turtles like in the Lakshadweep islands reflect a 'pristine' historical past, although the densities at these locations come close to historical estimates (as in Jackson 1997). Clearly, a suite of factors could precipitate these local increases, including effective conservation measures, habitat loss in other adjacent regions, global warming or shark overfishing, among others. In the Indo-Pacific region, overexploitation of large sharks may have led to a severe reduction in predatory control on green turtles. This may have triggered the population expansions currently being recorded at many locations across archipelagos in the western Indian Ocean and Indonesia (Ballorain 2010, Christianen et al. 2012, this study). It is perhaps not surprising that these regions also have among the largest shark fisheries globally (Lack \& Sant 2006). Whatever the reasons behind the encouraging trends of green turtle recovery (Broderick et al. 2006, Chaloupka et al. 2008) it becomes necessary to carefully determine forage requirements and carrying capacities of seagrass ecosystems (Bjorndal 1997, Moran \& Bjorndal 2005) that will be essential in supporting increasing turtle population densities. It follows that concerted turtle conservation efforts need to ensure that seagrass habitats are also adequately protected with all their functional complexity at large 
enough scales (Orth et al. 2006, Fourqurean et al. 2010, Unsworth \& Cullen 2010). This will help enhance their resilience to high-impact grazing by recovering populations of green turtles.

Acknowledgements. We thank the Norwegian Institute for Nature Research (NINA), Norway, and the Rufford Small Grants for Nature Conservation, UK, for providing funding support for the study. The Lakshadweep Administration provided timely permits for working in the islands. We thank M. D. Madhusudan, A. Lal, K. Shanker, J. Hisham, I. Babu, M. Gangal, R. Karkarey, M. K. Ibrahim and others who provided crucial inputs in the study. We thank 3 anonymous reviewers and the editors for providing critical reviews and invaluable suggestions that helped improve the article substantially. T.A. was partially supported by the Spanish Ministry of Science and Innovation (project CTM201022273-C02-02).

\section{LITERATURE CITED}

Alcoverro T, Mariani S (2004) Patterns of fish and sea urchin grazing on tropical Indo-Pacific seagrass beds. Ecography 27:361-365

Aragones LV (1996) A review of the role of the green turtle in tropical seagrass ecosystems www.arbec.com.my/seaturtles/art7julysept01.htm

Aragones LV, Lawler IR, Foley WJ, Marsh H (2006) Dugong grazing and turtle cropping: grazing optimization in tropical seagrass systems? Oecologia 149:635-647

Balazs G (2004) Thirty-year recovery trend in the once depleted Hawaiian green sea turtle stock. Biol Conserv 117:491-498

Ballorain K (2010) Ecologie trophique de la tortue verte Chelonia mydas dans les herbiers marins et algueraies du sud-ouest de 1 'Océan Indien. PhD dissertation, University of Reunion, Saint-Denis, p 71-92

Ballorain K, Ciccione S, Bourjea J, Grizel H, Enstipp M, Georges JY (2010) Habitat use of a multispecific seagrass meadow by green turtles Chelonia mydas at Mayotte Island. Mar Biol 157:2581-2590

Bjorndal KA (1985) Nutritional ecology of sea turtles. Copeia 1985:736-751

Bjorndal KA (1997) Foraging ecology and nutrition of sea turtles. In: Lutz PL, Musick JA (eds) The biology of sea turtles, Vol 1. CRC Press, Boca Raton, FL, p 199-231

Bjorndal KA, Jackson JBC (2003) Roles of sea turtles in marine ecosystems: reconstructing the past. In: Lutz PL, Musick JA, Wyneken J (eds) The biology of sea turtles, Vol 2. CRC Press, Boca Raton, FL, p 259-273

Broderick AC, Frauenstein R, Glen F, Jackson AL, Pelembe T, Ruxton GD, Godley BJ (2006) Are green turtles globally endangered? Glob Ecol Biogeogr 15:21-26

Burkholder DA, Heithaus MR, Thomson JA, Fourqurean JW (2011) Diversity in trophic interactions of green sea turtles Chelonia mydas on a relatively pristine coastal foraging ground. Mar Ecol Prog Ser 439:277-293

Cebrián J (1999) Patterns in the fate of production in plant communities. Am Nat 154:449-468

- Cebrián J, Duarte CM (1998) Patterns in leaf herbivory on seagrasses. Aquat Bot 60:67-82

- Cebrián J, Duarte CM, Marba N, Enriquez S (1997) Magni- tude and fate of the production of four co-occurring Western Mediterranean seagrass species. Mar Ecol Prog Ser 155:29-44

Cebrián J, Duarte CM, Agawin NSR, Merino M (1998) Leaf growth response to simulated herbivory: a comparison among seagrass species. J Exp Mar Biol Ecol 220: $67-81$

Cebrián J, Pedersen M, Kroeger K, Valiela I (2000) Fate of production of the seagrass Cymodocea nodosa in different stages of meadow formation. Mar Ecol Prog Ser 204: 119-130

Chaloupka M, Bjorndal KA, Balazs GH, Bolten AB and others (2008) Encouraging outlook for recovery of a once severely exploited marine megaherbivore. Glob Ecol Biogeogr 17:297-304

Christianen MJA, Govers LL, Bouma TJ, Kiswara W, Roelofs JGM, Lamers LPM, van Katwijk MM (2012) Marine megaherbivore grazing may increase seagrass tolerance to high nutrient loads. J Ecol 100:546-560

> Cronin G, Hay ME (1996) Susceptibility to herbivores depends on recent history of both the plant and animal. Ecology 77:1531-1543

Cyr H, Pace ML (1993) Magnitude and patterns of herbivory in aquatic and terrestrial ecosystems. Nature 361: 148-150

Domning DP (2001) Sirenians, seagrasses, and Cenozoic ecological change in the Caribbean. Palaeogeogr Palaeoclimatol Palaeoecol 166:27-50

Duarte CM, Cebrián J (1996) The fate of marine autotrophic production. Limnol Oceanogr 41:1758-1766

Duffy JE, Hay ME (1994) Herbivore resistance to seaweed chemical defense: the roles of mobility and predation risk. Ecology 75:1304-1319

Eklof J, de la Torre-Castro M, Gullström M, Uku J, Muthiga N, Bandeira S, Lyimo T (2008) Sea urchin overgrazing of seagrasses: a review of current knowledge on causes, consequences, and management. Estuar Coast Shelf Sci 79:569-580

Fourqurean JW, Manuel S, Coates KA, Kenworthy WJ, Smith SR (2010) Effects of excluding sea turtle herbivores from a seagrass bed: Overgrazing may have led to loss of seagrass meadows in Bermuda. Mar Ecol Prog Ser 419:223-232

Fourqurean JW, Duarte CM, Kennedy H, Marba N and others (2012) Seagrass ecosystems as a globally significant carbon stock. Nat Geosci 5:505-509

Hay ME, Renaud PE, Fenical W (1988) Large mobile versus small sedentary herbivores and their resistance to seaweed chemical defenses. Oecologia 75:246-252

Heck KL Jr, Valentine JF (2006) Plant-herbivore interactions in seagrass meadows. J Exp Mar Biol Ecol 330: 420-436

Heck KL Jr, Carruthers TJB, Duarte CM, Hughes AR, Kendrick G, Orth RJ, Williams SW (2008) Trophic transfers from seagrass meadows subsidize diverse marine and terrestrial consumers. Ecosystems 11:1198-1210

Heithaus MR, Frid A, Wirsing A, Worm B (2008) Predicting ecological consequences of marine top predator declines. Trends Ecol Evol 23:202-210

Jackson JBC (1997) Reefs since Columbus. Coral Reefs 16: $\mathrm{S} 23-\mathrm{S} 32$

Jackson JBC (2001) What was natural in the coastal oceans? Proc Natl Acad Sci USA 98:5411-5418

Jagtap T (1991) Distribution of seagrasses along the Indian coast. Aquat Bot 40:379-386 
Kirsch KD, Valentine JF, Heck KL Jr (2002) Parrotfish grazing on turtlegrass Thalassia testudinum: evidence for the importance of seagrass consumption in food web dynamics of the Florida Keys National Marine Sanctuary. Mar Ecol Prog Ser 227:71-85

Kuiper-Linley M, Johnson CR, Lanyon JM (2007) Effects of simulated green turtle re-grazing on seagrass abundance, growth and nutritional status in Moreton Bay, southeast Queensland, Australia. Mar Freshw Res 58: 492-503

Lack M, Sant G (2006) World shark catch, production and trade 1990-2003. TRAFFIC International, Cambridge

Lal A, Arthur R, Marba NR, Lill AWT, Alcoverro T (2010) Implications of conserving an ecosystem modifier: increasing green turtle (Chelonia mydas) densities substantially alters seagrass meadows. Biol Conserv 143:2730-2738

Lundberg J, Moberg F (2003) Mobile link organisms and ecosystem functioning: implications for ecosystem resilience and management. Ecosystems 6:87-98

Mateo MA, Cebrián J, Dunton K, Mutchler T (2006) Carbon flux in seagrass ecosystems. In: Larkum AWD, Orth RJ Duarte CM (eds) Seagrasses: biology, ecology and conservation. Springer, Dordrecht, p 159-192

Moran KL, Bjorndal KA (2005) Simulated green turtle grazing affects structure and productivity of seagrass pastures. Mar Ecol Prog Ser 305:235-247

Moran KL, Bjorndal KA (2007) Simulated green turtle grazing affects nutrient composition of the seagrass Thalassia testudinum. Mar Biol 150:1083-1092

Nakanishi Y, Adulyankusool K, Arai N, Hosoya S, Nakanishi Y, Kotani K, Katsukoshi K (2009) The relationship between dugong grazing pressure on seagrass meadows and seagrass adaptations. J Adv Mar Sci Tech Soc 15: $23-27$

Orth RJ, Carruthers TJB, Dennison WC, Duarte CM and others (2006) A global crisis for seagrass ecosystems. Bioscience 56:987-996

Prado P, Tomas F, Alcoverro T, Romero J (2007) Extensive direct measurements of Posidonia oceanica defoliation confirm the importance of herbivory in temperate seagrass meadows. Mar Ecol Prog Ser 340:63-71

Prado P, Farina S, Tomas F, Romero J, Alcoverro T (2008) Marine protection and meadow size alter fish herbivory in seagrass ecosystems. Mar Ecol Prog Ser 371:11-21

Preen A (1995) Impacts of dugong foraging on seagrass habitats: observational and experimental evidence for cultivation grazing. Mar Ecol Prog Ser 124:201-213

R Development Core Team (2011) R: A language and environment for statistical computing. R Foundation for Statistical Computing, Vienna

Seminoff JA (2004) Chelonia mydas. In: IUCN 2011. IUCN Red List of Threatened Species. Version 2011.2. www. iucnredlist.org (accessed 13 November 2012)
Short FT, Coles RG (eds) (2001) Global seagrass research methods. Elsevier Science, Amsterdam

Thayer GW, Engel DW (1982) Evidence for short-circuiting of the detritus cycle of seagrass beds by the green turtle Chelonia mydas L. J Exp Mar Biol Ecol 62:173-183

Thayer GW, Bjorndal KA, Ogden JC, Williams SL, Zieman JC (1984) Role of larger herbivores in seagrass communities. Estuaries 7:351-376

Unsworth RKF, Cullen LC (2010) Recognizing the necessity for Indo-Pacific seagrass conservation. Conserv Lett 3: 63-73

Unsworth RKF, Taylor JD, Powell A, Bell JJ, Smith DJ (2007) The contribution of scarid herbivory to seagrass ecosystem dynamics in the Indo-Pacific. Estuar Coast Shelf Sci 72:81-88

Valentine JF, Duffy JE (2006) The central role of grazing in seagrass ecology. In: Larkum AWD, Orth RJ, Duarte CM (eds) Seagrasses: biology, ecology and conservation. Springer, Dordrecht, p 463-501

Valentine JF, Heck KL Jr (1999) Seagrass herbivory: evidence for the continued grazing of marine grasses. Mar Ecol Prog Ser 176:291-302

Valentine JF, Heck KL Jr (2001) The role of leaf nitrogen content in determining turtlegrass (Thalassia testudinum) grazing by a generalized herbivore in the northeastern Gulf of Mexico. J Exp Mar Biol Ecol 258:65-86

Valentine JF, Valentine JF, Heck KL, Busby J, Webb D (1997) Experimental evidence that herbivory increases shoot density and productivity in a subtropical turtlegrass (Thalassia testudinum) meadow. Oecologia 112: 193-200

Valentine JF, Blythe EF, Madhavan S, Sherman TD (2004) Effects of simulated herbivory on nitrogen enzyme levels, assimilation and allocation in Thalassia testudinum. Aquat Bot 79:235-255

Vergés A, Becerro MA, Alcoverro T, Romero J (2007) Variation in multiple traits of vegetative and reproductive seagrass tissues influences plant-herbivore interactions. Oecologia 151:675-686

Vonk JA, Christianen MJA, Stapel J (2010) Abundance, edge effect, and seasonality of fauna in mixed-species seagrass meadows in southwest Sulawesi, Indonesia. Mar Biol 6:282-291

Williams SL (1988) Thalassia testudinum productivity and grazing by green turtles in a highly disturbed seagrass bed. Mar Biol 98:447-455

Williams SL, Heck KL Jr (2001) Seagrass community ecology. In: Bertness M, Gaines S, Hay M (eds) Marine community ecology. Sinauer Press, Sunderland, MA, p $317-337$

Zieman JC, Iverson R, Ogden L (1984) Herbivory effects on Thalassia testudinum leaf growth and nitrogen content. Mar Ecol Prog Ser 15:151-158

Submitted: June 20, 2012; Accepted: April 19, 2013

Proofs received from author(s): June 10, 2013
Editorial responsibility: Kenneth Heck Jr.,

Dauphin Island, Alabama, USA 